\title{
実存的アプローチによるデス・エデュケーションプログラムの 効果研究
}

宮崎 圭子

跡見学園女子大学

キーワード : デス・エデュケーション, 実存的アプローチ, 時間イメージ, 実存性

(ストレス科学研究 2015, 30, 150-156)

\begin{abstract}
The present study evaluated the effectiveness of a death-educational program based on an existential approach for improving time and existential attitudes. 15 undergraduate students were assigned to the program. The intervention was composed of one $90 \mathrm{~min}$. session and 3 exercises. All participants saw some parts of a movie where a mother suffers from her son's leukemia. Afterwards, they discussed the reasons the mother's suffering is went away. They completed questionnaires measuring time and existential attitudes before and after the program. The results indicated that the group had improved time and existential attitudes. In addition, it was discussed how they changed in the program.

Keywords: death-education, existential approach, time attitudes, existential attitudes
\end{abstract}

\section{1. 問題と目的}

デス・エデュケーションには大きく分けて二つあ る1)。一つは，死に直面した人の死への不安を軽減す るためのデス・エデュケーションである。二つ目は, 健常者に対して死を見つめ今生きていることを感じさ せるものである。特に後者のデス・エデュケーション に関して，Deeken は死をタブー視せず身近な問題と して考え, 生と死の意義を探求し, 自覚を持って自己 と他者の死にそなえての心構えをさせることの重要性 を説く。死をみつめることで時間の貴重さを発見し, 人間の創造的次元を刺激し, 価值観の見直しと再評価 が促されるからである2)。

Wong \& Tomer は, 死の否認はストレスや抑うつ のような様々な様相を生むと主張する。さらには死の 受容は well-being に達するための適切な方法である とも述べている3゙。また，石井は死について考えるこ
とが時間的態度を肯定的に変容させることを実証し た ${ }^{4)}$ 。時間的態度とは, 過去 · 現在 ·未来に対する感 情的評価のことである ${ }^{5)}$ 。

一方で, 戸田・宮崎は情動的アプローチのデス・エ デュケーションプログラムを, Furr のサイコエデュ ケーション (心理教育) の「6ステップモデル」6）を もとに作成した $\left(\right.$ Table 1) ${ }^{1}$ 。 $。$ この゚ログラムのデス エデュケーションは感情レベルの変化を目的としたも のである。サイコエデュケーションと同様 ${ }^{7}$, デス エデュケーションは認知的アプローチのプログラムが 多い1)。しかしながら, Furr によれば, サイコエデュ ケーションはアプローチによって, 認知レベル, 感情 レベル, 行動レベル, 実存レベル, 身体的レベルで変 化を起こすことができる6)。また，成瀬は適度なレべ ルのイメージを適切に表出し体感することで，その人 の現実性が高まると主張している8 ${ }^{8)}$ 。上述した戸田・ 宮崎が作成した情動的アプローチのデス・エデュケー ションの効果を検討したところ, $1 \%$ 水準で時間イメー

Effectiveness of a death-educational program based on an existential approach

Keiko Miyazaki

Atomi University 
Table 1 Furr によるサイコエデュケーション 6 ステップモ デル6)

\begin{tabular}{ll}
\hline ステップ 1 & 目的の宣言 \\
ステップ 2 & ゴール \\
ステップ 3 & 目標 (ゴールのための) \\
ステップ 4 & コンテンッ \\
ステップ 5 & エクササイズ \\
ステップ 6 & 評価 \\
\hline
\end{tabular}

ジと未来イメージが, $0.1 \%$ 水準で現在イメージがポ ジィテイブな方に変化した。死を感じることで時間の 貴重さを感じ, 現在と未来がポジティブに変化したと 考察した。

先述したように, サイコエデュケーションはアプ ローチによって, 認知レベル, 感情レベル, 行動レベ ル，実存レベル，身体的レベルで変化を起こすことが できる ${ }^{6)}$ 。認知的アプローチのデス・エデュケーショ ンは少なからず報告されている。情動的アプローチの デス・エデュケーションのプログラムは戸田・宮崎が 作成した ${ }^{1)}$ 。では, 実存的アプローチ，つまり実存レ ベルの変化を起こすデス・エデュケーションは可能だ ろうか。

実存とは「特に人間的実存を意味し，自己の存在に 関心をもつ主体的な存在, 絶えざる自己超克を強いら れている脱自的存在をいう」と説明されている9 ${ }^{9)}$ 。実 存主義とは, 日常生活において自身を「主体的な存在」 として捉え，他なら自分自身の人生を主体的に生き 抜く存在であり続けることなのである。そして，心理 療法に括ける実存主義的アプローチでは, 主体として の自分自身について少しずつ気づいていくことが強調 されるのである ${ }^{10)}$ 。実存主義では，自身の実感にも とづいて行動し, 自身にとって意味ある行動をし, そ れゆえに己の行動の全責任を引き受けることを良しと する ${ }^{11)}$ 。そこには，人間とは自ら決断することので きる主体であり，生きているただ中においてさえ自分 を変えることのできる存在とみる人間観がある ${ }^{12)}$ 。 人生には一般的解答のない, 避けられない問題がある。 例えば, 死, 孤独, 生きる意味などである。人とは, これらの問題に自ら独自の答えを出して生きていかね ばならない存在なのである ${ }^{13)}$ 。そのため, 実存主義 的アプローチでは価值観を論ずることになる ${ }^{14)}$

また, Prochaska \& Norcross は, 無意味であること, 孤立, 孤独, 有限性が不安をもたらす条件であると説 く。死は時間の有限性の反映であり, 自己は力の限界 を示していることが実存不安を生み出すのである ${ }^{10) 。 ~}$ 人は運命的な死から逃れることはできない。同様に孤 独等に陥る可能性も持っている。なおかつ, 選択の自 由も持ち, さらにはそれに対して責任を負わねばなら
ない。このような現実のなかで, 人が感じる不安を実 存不安という ${ }^{14)}$ 。

実存において，実存不安の根源である「死」（死の タブー視とつながる）と，「主体的に生きること」は 重要な概念として捉えることができる。先述したよう に, Deeken が主張するデス・エデュケーションの意 義は，死をタブー視せず向き合うことで，価值観の見 直しと再評価が促されるからであった ${ }^{2)}$ 。そのため実 存主義とデス・エデュケーションには共通するものが あると考える。有限性を意味する死に向き合うデス。 エデュケーションにおいて，「主体的に生き，そして その生きる意味を見出す」ようなプログラムを作成す ることで, Furr が主張する実存レベルの変化を引き 起こせるのではないだろうか6)。さらには, 実存不安 の根源である「死」(死のタブー視とつながる) と向 き合うことによって, Wong \& Tomerが主張するス トレス ${ }^{3)}$ も軽減されるのはないだろうか?

以上より本研究の目的は, 実存的アプローチのデス・ エデュケーションプログラムの作成と, その効果を検 討することとした。

\section{2. 方 法}

\section{1 対象者}

関東圈内 X女子大学学部 3 年生 15 名が本デス・エ デュケーションプログラムに参加した。このデス・エ デュケーションのプログラムは, サイコエデュケー ションの枠組みで構成されている。Coreyは, サイコ エデュケーションのグループサイズは，1人の専門家 に対して 4 人〜 8 人が理想であると報告している ${ }^{15)}$ 。 今回, 15 名ということで若干多いが, 後述している 予備実験（14名）の結果を踏まえ, 15 名でも可能と 判断した。

\section{2 実施時期}

2014 年 6 月下旬に実施した。

\section{3 質問紙内容}

\subsection{1 時間イメージ尺度 ${ }^{16)}$}

時間的展望とはある一定の時点における個人の心理 学的過去および未来についての見解の総体のことであ る ${ }^{17)}$ 。都筑は, イメージや態度の測定方法として知 られる Semantic Differential Method（SD 法）を使っ て，この時間的展望が評価される時間イメージ尺度を 作成した ${ }^{16)}$ 。過去, 現在, 未来のそれぞれのイメー ジは, 各 20 の形容詞対から成り, 合計 60 項目を 7 段 階で評定する。Table 2 に示した。本尺度を採用した のは, 時間イメージ（現在イメージ）がストレス反応 
Table 2 時間イメージ尺度項目 (過去, 現在, 未来各20項目 $)^{16)}$

\begin{tabular}{|c|c|}
\hline 1 & 楽しくないー楽しい \\
\hline 2 & 空虚なー満ち足りた \\
\hline 3 & 恐ろしいーすばらしい \\
\hline 4 & 魅力のない - 魅力のある \\
\hline 5 & 冷たいーあたたかい \\
\hline 6 & 暗い－明るい \\
\hline 7 & 希望のない - 希望のある \\
\hline 8 & 遅いー速い \\
\hline 9 & 困難なー容易な \\
\hline 10 & 遠い-近い \\
\hline 11 & 重要でないー重要な \\
\hline 12 & 短いー長い \\
\hline 13 & 小さいー大きい \\
\hline 14 & 悪い-良い \\
\hline 15 & 単調なー変化に富んた \\
\hline 16 & あいまいなーはっきりした \\
\hline 17 & 不安定な－安定な \\
\hline 18 & とじたーあけはなした \\
\hline 19 & 活気のないー生き生きした \\
\hline 20 & 受身的な - 能動的な \\
\hline
\end{tabular}

と負の強い相関があるからであり ${ }^{18)}$ ，回答するのに 負担がかからないからである。「あなたご自身の現在 （過去，未来）をイメージしてください。下の〈各対 の表現〉を見て，一番よく当てはまるところの数字の *に, 1 つだけ○をつけてください。」という教示で あった。それぞれ 20 項目からなる現在, 過去, 未来 の合計点を 20 で除したものを下位尺度得点とし, 現 在イメージ, 過去イメージ, 未来イメージとした。ま た，60 項目の合計点を 60 で除したものを時間イメー ジとした。

\subsubsection{Life Attitude Profile (LAP) ${ }^{19)}$}

LAP は，「人生の意義と目的を見出している度合」 と「人生の意義と目的を見出そうとする動機の強さ」 を評定するために, Reker \& Peacock が7 段階評価・ 49 項目で作成した尺度である ${ }^{20)}$ 。この日本版の LAP （3）は 7 因子 29 項目からなる ${ }^{19)}$ 。このうち, 実存度 を測定できると判断した第 5 因子「人生の意味と目的 の欲求」(3 項目), 第 6 因子「人生の統御」(3 項目) を用いた。Table 3 に示す。「あなたの今の気持ちや考
えについて㧍聞きします。以下の項目について，最も 当てはまるところに○印をつけて下さい。」と教示し， 7 段階評定するよう求めた。それぞれ第 5 因子, 第 6 因子の合計点を 3 で除したものを下位尺度得点とし， 人生の意味と目的の欲求, 人生の続御とした。

なお，回答時間を統一するために，質問紙回答はす べて強制速度法で行った。

2.3.3 その他

フェースシート (つらい死別経験の有無, 死に対し ての関心など), 死生観尺度（7因子 27 項目）の項目 にも回答を求めている。しかしながら, 本研究の目的 外の尺度により, 本論文の分析対象から除外した。そ のため,ここでは詳細は省略する。

\section{4 実存的アプローチのデス・エデュケーション プログラムの構成}

サイコエデュケーション (心理教育) とは「臨床フ レームでは解決できなくなった個々人の心理的かつ多 様な問題に対処する, 教育フレーム（心理的なスキル を教授することに焦点を当てる）からの広い意味での カウンセリングのアプローチである」と定義され る ${ }^{21)}$ 。デス・エデュケーションは, サイコエデュケー ションの枠組みで考えることができる1)。Furr のサイ コエデユケーションの「6ステップモデル」」) (Table 1) に基づき，以下のように作成した。

ステップ 1 : 目的の設定

実存的アプローチのデス・エデュケーションを通し て、「死」を見つめて「主体的に生きる」ということ を考えることとした。

ステップ 2：ゴールの決定

「時間イメージ」をポジティブな方へ変化させ，か つ実存度をあげる。

ステップ3：(ゴールのための）目標の設定

(1)映像を観て，感じたことの整理をする。

(2)「主体的に生きる」を議論し内省する。

(3)「主体的に生きる」に対する他者の意見をシェア リングする。

ステップ 4 : 内容の選択

実存的なアプローチの内容とする。つまりは, 死と

Table 3 Life Attitude Profile（第 5 因子, 第 6 因子 $)^{19)}$

\begin{tabular}{l}
\hline 第 5 因子: 人生の意味と目的の探求 \\
私は常に人生の意味を知りたいと思っています \\
私は常に, 自分の人生で自己とは何かを知りたいという強い気持ちを持っています \\
$\quad$ 私はいつも人生の意味・目的そして使命を探し続けています \\
第 6 因子 : 人生の統御 \\
私の生き方は, 自分の意志で決定したものです \\
私の人生でやれること, 大部分私自身の努力で達成できます \\
私は人に左右されることなく, 自分の人生を生きたいように生きることができます \\
\hline
\end{tabular}


Table 4 本デス・エデュケーションのプログラムの手順

\begin{tabular}{|c|c|c|}
\hline 手順番号 & 内容 & 所要時間 \\
\hline 1 & $\begin{array}{l}\text { ·実験者の自己紹介 } \\
\text { ·資料の配布:A4サイズの封筒に入った資料（質問紙,「ジョーイ」のあらすじ, ディスカッショ } \\
\text { ン時の教示,「ジョーイ」の感想を記述する用紙, デス・エデュケーションプログラムの感 } \\
\text { 想を記述する用紙) } \\
\text { ·デス・エデュケーションの概要説明とディスカッション時のグルーピング }\end{array}$ & 約 5 分 \\
\hline 2 & pre 質問紙に記入 & 約 10 分 \\
\hline 3 & エクササイズ 1: 視聴覚刺激動画「ジョーイ」（母親の葛藤場面）を見る, 感想を記述 & 約 15 分 \\
\hline 4 & エクササイズ 2：視聴覚刺激動画「ジョーイ」(スピーチシーン）を見た後ディスカッション & 約 30 分 \\
\hline 5 & 全体シェアリング & 約 10 分 \\
\hline 6 & post 質問紙および最終の感想を記入 & 約 15 分 \\
\hline
\end{tabular}

向き合う事で, 主体的に生きる事とは何かを考えさせ る。そのために, 1997 年公開の実話をもとにした映 画「ジョーイ」を採用。当時，不治の病であった白血 病に罹った 11 歳の息子ジョーイは，非常に辛い治療 を続けている。それを間近に見続けている母親は, 治 療することを選択したことが正しい道であるのかと葛 藤する。その葛藤の中で，母親はその答えを見出すと いうストーリィー。この映画を選んだ理由は，「母親 のその答え」の内容を明らかにせず映画が終わるとい う展開にある。「は二度と迷わなかった。」旨の姉(役) のナレーションが入るだけである。視聴者にその答え を想像させる, 考えさせる余地があると考えたからで ある。その映像を見せて, 人生とは一般的解答のない 問題に自ら独自の答えを出して生きていかねばならな いものであること ${ }^{13)}$ ，そうすることが主体的に生き る事に繋がるということ积を考えさせる。

ステップ 5：エクササイズのデザイン

(1)母親が葛藤に苦しむという場面。参加者はその場 面を観て, 感想を書く。

(2)ジョーイの母親がそれまでの葛藤に「答え」を見 出すシーンを観る。その後, 参加者はグループ デイスカッションをする。ディスカッションの テーマは「なぜ母親は二度と迷わなかったのか? 」 とした。

(3)最後に全体でシェアリング。 エクササイズとして，ライティングとグループ ディスカッションを採用した。Furr は実存レベ ルでの変化を目的としたサイコエデュケーション プログラムの鍵となるものは, 体験活動とその活 動を自身のなかで加工処理すること（つまり，体 験を言語化したり，議論すること等）だと主張し ているからである6)。

ステップ 6 : 評価

時間イメージ尺度 ${ }^{16)}$, Life Attitude Profile ${ }^{19)}$ を用 いる。

\section{5 予備実験}

事前に 2014 年 5 月中旬, 関東圈内 X女子大学大学 院修士課程 1 年生 14 名に予備実験を実施した。その 目的はディスカッションのエクササイズが促進される 要因を探ること, 使用する映像が適切であるかの判断 を行う，以上の 2 点であった。その予備実験の結果， デイスカッションの時間を 15 分に, グループ人数を 3 人組みに変更した。ディスカッションの教示文内容 を加筆し，配付するとともに口頭で読み上げるスタイ ルに変更した。さらにディスカッションの前に参加者 が自身の感情に向き合い文字に表現するエクササイズ を追加した。本プログラムを Table 4 に示す。

なお, 予備実験前後を通して, 臨床心理学専攻の大 学院生 2 名および臨床心理学専攻の教員 1 名で検討し ながら，プログラムの作成を行った。

本研究は筆者の所属している大学の倫理委員会にお いて厳正な審査を受け承認されている（承認番号 14006)。

\section{3. 結 果}

\section{1 実存的アプローチのデス・エデュケーション の効果検討}

本デス・エデュケーションプログラムの効果を検討 するために, 対応のある $t$ 検定を行った。従属変数は, 時間イメージ (過去, 現在, 未来), LAP, および各 尺度のそれぞれの質問項目（計 66 項目）である。なお, サンプル数が 25 名以下のため, 多変量分散分析を使 用しなかった ${ }^{22)}$ 。結果を Table 5 に示す。時間イメー ジ, 未来イメージが有意にポジティブな方へ変化した。 現在イメージが有意にポジティブな方へ変化する傾 向, 人生の統御が有意に増加する傾向が認められた。 また, 人生の統御の質問項目「私の人生でやれること は，大部分私自身の努力で達成できます」「私は人に 左右されることなく, 自分の人生を生きたいように生 
Table 5 対応のある $t$ 検定結果

\begin{tabular}{|c|c|c|c|c|c|c|}
\hline & & \multicolumn{2}{|c|}{ pre } & \multicolumn{2}{|c|}{ post } & \multirow{2}{*}{$t$ 值 } \\
\hline & & $M$ & $S D$ & $M$ & $S D$ & \\
\hline 第 5 因子 & 人生の意味と目的の欲求 & 4.44 & 1.09 & 4.62 & 1.10 & 1.29 \\
\hline 第 6 因子 & 人生の統御 & 4.58 & 0.74 & 4.96 & 0.17 & $1.91^{\dagger}$ \\
\hline \multirow{3}{*}{$\begin{array}{l}\text { 第 } 5 \text { 因子の } \\
\text { 項目 }\end{array}$} & 私は常に人生の意味を知りたいと思っています & 4.47 & 1.55 & 4.87 & 1.46 & $1.87^{\dagger}$ \\
\hline & $\begin{array}{l}\text { 私は常に, 自分の人生で自己とは何かを知りたいという強い気 } \\
\text { 持ちを持っています }\end{array}$ & 4.80 & 1.27 & 4.87 & 1.51 & 0.29 \\
\hline & 私はいつも人生の意味・目的そして使命を探し続けています & 4.07 & 1.22 & 4.13 & 0.92 & 0.44 \\
\hline \multirow{3}{*}{$\begin{array}{l}\text { 第 } 6 \text { 因子の } \\
\text { 項目 }\end{array}$} & 私の生き方は, 自分の意志で決定したものです & 4.73 & 1.39 & 4.93 & 0.96 & 0.59 \\
\hline & 私の人生でやれることは, 大部分私自身の努力で達成できます & 4.67 & 0.98 & 5.07 & 1.16 & $2.45^{*}$ \\
\hline & $\begin{array}{l}\text { 私は人に左右されることなく, 自分の人生を生きたいように生 } \\
\text { きることができます }\end{array}$ & 4.33 & 1.05 & 4.87 & 0.83 & $2.26^{*}$ \\
\hline \multirow{4}{*}{$\begin{array}{l}\text { 時間 } \\
\text { イメージ }\end{array}$} & 時間イメージ & 4.23 & 0.75 & 4.61 & 0.80 & $2.49^{*}$ \\
\hline & 現在イメージ & 4.36 & 0.97 & 4.73 & 0.97 & $1.80^{\dagger}$ \\
\hline & 過去イメージ & 3.53 & 1.06 & 3.95 & 1.20 & 1.76 \\
\hline & 未来イメージ & 4.81 & 0.82 & 5.14 & 0.93 & $2.48^{*}$ \\
\hline \multirow{4}{*}{$\begin{array}{l}\text { 現在 } \\
\text { イメージ }\end{array}$} & 単調なー変化に富んだ & 4.13 & 1.36 & 5.07 & 1.16 & $2.29^{*}$ \\
\hline & 不安定な -安定な & 3.67 & 1.95 & 4.53 & 1.36 & $2.58^{*}$ \\
\hline & 遅い－速い & 4.07 & 1.39 & 4.40 & 1.30 & $1.78^{\dagger}$ \\
\hline & 悪い-良い & 4.60 & 1.06 & 5.13 & 1.06 & $2.09^{\dagger}$ \\
\hline \multirow{7}{*}{$\begin{array}{l}\text { 過去 } \\
\text { イメージ }\end{array}$} & 悪い-良い & 3.07 & 1.39 & 4.00 & 1.65 & $2.71^{*}$ \\
\hline & 不安定な－安定な & 2.60 & 1.50 & 3.67 & 1.59 & $2.87^{*}$ \\
\hline & とじたーあけはなした & 3.00 & 1.56 & 3.80 & 1.66 & $2.26^{*}$ \\
\hline & 恐ろしいーすばらしい & 3.73 & 1.16 & 4.27 & 1.10 & $2.09^{\dagger}$ \\
\hline & 遅い－速い & 3.53 & 1.13 & 4.20 & 1.47 & $2.00^{\dagger}$ \\
\hline & 短いー長い & 4.87 & 0.92 & 4.20 & 1.08 & $2.00^{\dagger}$ \\
\hline & 活気のないー生き生きした & 3.20 & 1.70 & 4.07 & 1.83 & $1.99^{\dagger}$ \\
\hline \multirow{7}{*}{$\begin{array}{l}\text { 未来 } \\
\text { イメージ }\end{array}$} & 魅力のない-魅力のある & 5.00 & 1.25 & 5.47 & 1.19 & $2.17^{*}$ \\
\hline & 短い-長い & 4.27 & 1.28 & 4.87 & 1.25 & $2.80^{*}$ \\
\hline & あいまいなーはっきりした & 4.33 & 1.05 & 4.93 & 1.16 & $2.36^{*}$ \\
\hline & 楽しくないー楽しい & 5.20 & 1.08 & 5.60 & 1.06 & $1.87^{\dagger}$ \\
\hline & 小さい-大きい & 4.47 & 1.41 & 4.93 & 1.10 & $1.83^{\dagger}$ \\
\hline & 悪い-良い & 5.13 & 1.06 & 5.47 & 1.06 & $2.09^{\dagger}$ \\
\hline & とじたーあけはなした & 4.60 & 0.91 & 4.93 & 1.44 & $1.78^{\dagger}$ \\
\hline
\end{tabular}

きることができます」が増加していた。現在イメージ が「変化に富んだ, 安定な」方へ, 過去イメージが「良 い，安定な」方へ，未来イメージが「魅力のある，長 い,はっきりした」方へ変化していた。

\section{4. 考察}

\section{1 実存的アプローチによるデス・エデュケー ションプログラムの効果検討}

人生の統御, 時間イメージ, 現在イメージ, 未来イ メージがポジティブな方へ変容した。特に，人生の統 御が増えた傾向が確認できた。また, 人生の統御の質 問項目「私の人生でやれることは，大部分私自身の努 力で達成できます」「私は人に左右されることなく，
自分の人生を生きたいように生きることができます」 が増加したことも認められた。実存的アプローチは, 先述したように人間とは自ら決断することのできる主 体であるとする考えをもっている。本プログラムは Furr がいうところの実存レベル6）での変化が起きた と考えてよいだろう。

このことは, 3 回（母親の葛藤シーン直後・「なぜ 母親は二度と迷わなかったのか？」をテーマにグルー プディスカッション直前・最終の感想）に渡って記述 してもらったコメントによっても推察される (Table 6)。殆どの参加者が「生きること」について色々 考えさせられたとコメントしていた。さらには，スト レス反応と負の相関がある現在イメージ18) がポジ ティブな方へ変容したことは, 本プログラムがストレ 


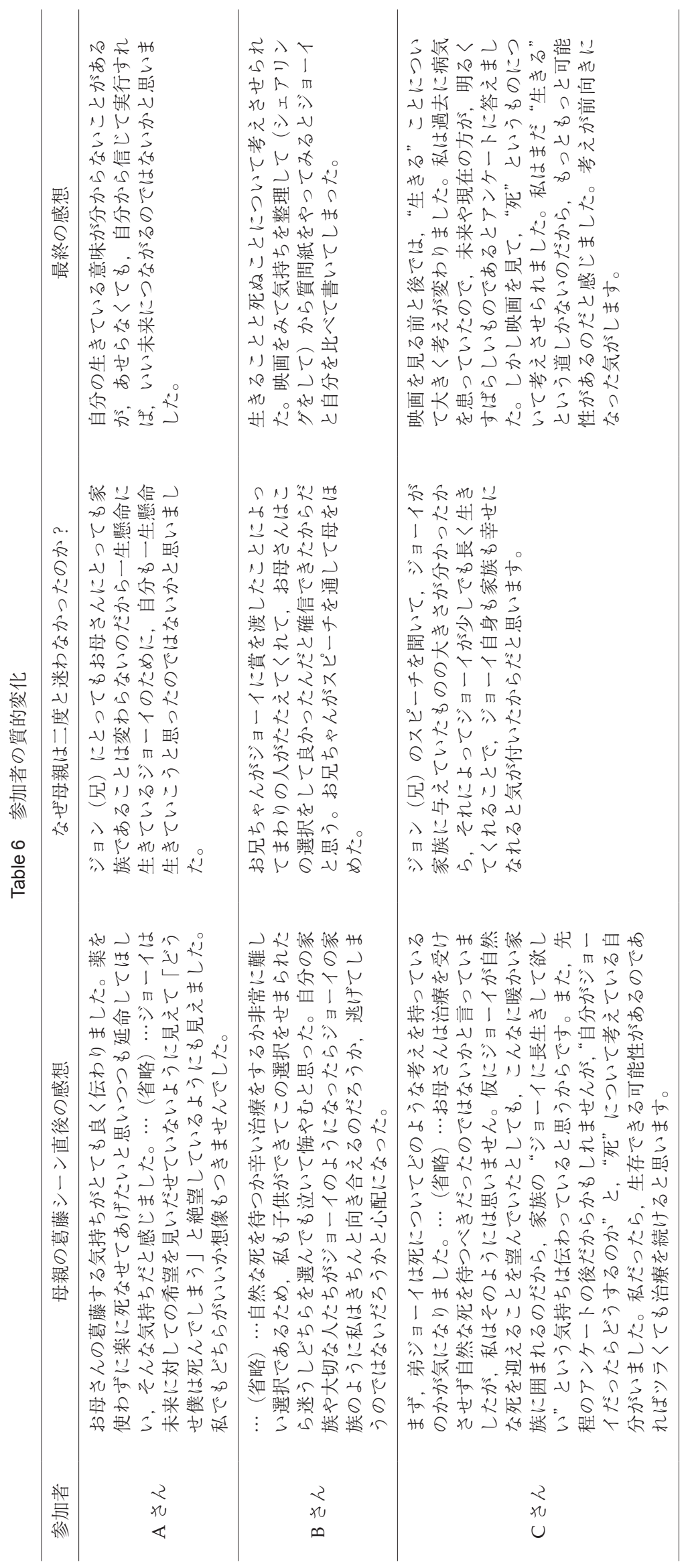


スを軽減させる可能性があることも示唆している。 本プログラムでは「なぜ母親は二度と迷わなかった のか？」のテーマでグループディスカッションする エクササイズを採用した。テーマが難しかったのか, デイスカッション形式そのものが難しいエクササイズ であったのか, 期待していたような活発な議論とはな らなかった。グループ内で自身の意見を披露しグルー プシェアリングしたという印象であった。「グループ で無理に意見をまとめなくてよい」と教示したことが 原因かもしれない。「グループで意見をまとめてほし い」と教示した方が活発な議論展開になったのかもし れない。

\section{2 今後の課題}

本研究の参加者は女子大生 15 名であった。男性, 成人期，思春期など多様なグループに対しての効果を 検証することが今後の課題となるだろう。また，統制 群の設定をしての効果検証も必要であろう。

\section{文 献}

1) 戸田恵美子, 宮崎圭子, 「今を生きる」デス・エデュケー ションプログラムの効果研究—死別経験・死への関心と の関連一. 跡見学園女子大学附属心理教育相談所紀要 11, 31-41, 2014

2) Deeken, A., 死とどう向き合うか. NHK出版, 1996.

3) Wong, P. P., Tomer, A., Beyond terror and denial: The positive psychology of death acceptance. Death Studies 35, 99-106, 2011.

4) 石井 僚, 青年期に抢いて死について考える事が時間的 態度に及ぼす影響．教育心理学研究 61, 229-238, 2013.

5) 白井利明, 時間的展望の生涯発達に関する研究の到達点 と課題。大阪教育大学紀要 42, 187-216, 1994.

6) Furr, S. R., Structuring the group experience: A format for designing psychoeducational groups. Journal for specialists in group work 25, 29-49, 2000.

7) 宮崎圭子，サイコエデュケーションの理論と実際。遠見
書房, 2013.

8) 成瀬悟策，自己コントロール法. 誠信書房，1988.

9) 新村出編，広辞苑第 6 版。岩波書店， 2008.

10) Prochaska, J. O., Norcross, J. C., Systems of Psychotherapy A Transtheoretical Analysis. Brooks: Cenegage Learning Co., 2007. (津田 彰, 山崎久美子監訳, 心理療法の諸 システム一他理論統合的分析一. 金子書房, 2010.)

11）上嶋洋一, 実存主義. 國分康孝編，カウンセリング辞典. 誠信書房, 1993.

12）諸富祥彦, 実存主義的アプローチ. 國分康孝編, カウン セリング辞典。誠信書房, 1993.

13）國分康孝, カウンセリングの理論. 誠信書房, 1993.

14）正保春彦, 実存的不安. 國分康孝編, カウンセリング辞 典. 誠信書房, 1993

15) Corey, G., The theory and practice of group counseling ( $5^{\text {rd }}$ ed.). Pacific Grove, CA: Brooks/Cole., 1999.

16）都筑 学, 大学生における自我同一性と時間的展望. 教 育心理学研究 41, 40-48, 1993.

17) Lewin, K., Field Theory and Social Science. New York: Harper, 1951. (猪股佐登留訳, 社会科学における場の理 論. 誠信書房, 1974.)

18）宮崎圭子, 9 分割統合絵画法のサイコエデュケーショナ ル・グループワークへの応用一就労学生達への援助アプ ローチ一．産業カウンセリング研究 7, 17-23, 2004.

19）中村昭之, 林潔, 板津裕己, 人生に対する態度の研 究 (2) - LAP (Life Attitude Profile) の研究一. 駒沢 社会学研究 20, 93-129, 1988.

20) Reker, G. T., Peacock, E. J., The Life Attitude Profile (LAP): A Multidimensional Instrument for Assessing Toward Life. Canadian J. of Behavioral Science 13(3), 264273, 1981.

21) 岡林春雄, 心理教育-psychoeducation一. 金子書房, 1997.

22) Kirk, R., Experimental Design. Pacific Grove, Ca: Brooks/ Cole Publishing, 1982. 